\title{
Corporate Governance and Corporate Reputation: The Role of Environmental and Social Reporting Quality
}

\author{
Mohamad Iruwan Ghuslan ${ }^{1}$, Romlah Jaffar ${ }^{2, *}$, Norman Mohd Saleh ${ }^{2}$ and Mohd Hasimi Yaacob ${ }^{2}$ (D) \\ 1 Faculty of Business, Multimedia University, Bukit Beruang, Melaka 75450, Malaysia; \\ mohamad.iruwan@mmu.edu.my \\ 2 Faculty of Economics and Management, Universiti Kebangsaan Malaysia, Bangi 43600, Selangor, Malaysia; \\ norman@ukm.edu.my (N.M.S.); mhasimi@ukm.edu.my (M.H.Y.) \\ * Correspondence: romlah@ukm.edu.my; Tel.: +60-3-89213414
}

Citation: Ghuslan, M.I.; Jaffar, R.; Mohd Saleh, N.; Yaacob, M.H.

Corporate Governance and Corporate Reputation: The Role of

Environmental and Social Reporting Quality. Sustainability 2021, 13, 10452. https://doi.org/10.3390/su131810452

Academic Editors:

Izabela Jonek-Kowalska and Lilla Knop

Received: 23 July 2021

Accepted: 17 September 2021

Published: 20 September 2021

Publisher's Note: MDPI stays neutral with regard to jurisdictional claims in published maps and institutional affiliations.

Copyright: (c) 2021 by the authors. Licensee MDPI, Basel, Switzerland. This article is an open access article distributed under the terms and conditions of the Creative Commons Attribution (CC BY) license (https:// creativecommons.org/licenses/by/ $4.0 /)$.

\begin{abstract}
Corporate reputation is companies' most valuable asset as it can position them to gain competitive advantages that lead to sustainable performance. Therefore, understanding the factors that influence corporate reputation is vital for a company's survival. The study objectives were to investigate the effects of corporate governance and the quality of environmental and social reporting on corporate reputation. Additionally, this study examined the role of environmental and social reporting quality on the relationship between these two variables. This study used secondary data collected from multiple sources such as the Thomson Data Stream database and annual reports of publicly listed Malaysian companies between 2017 and 2018. The results showed that corporate governance effectiveness and environmental and social reporting quality positively influence corporate reputation. Additionally, the quality of environmental and social reporting mediates the relationship between corporate governance and corporate reputation. This study bridges research gaps by providing evidence for the impact of effective corporate governance, specifically board diversity, on corporate reputation in Malaysia. The findings can help companies to establish criteria and qualifications for the appointment of new board members. The members must have the right combination of skills, knowledge, experience and independent elements that enable them to make decisions to meet companies' objectives.
\end{abstract}

Keywords: corporate reputation; corporate governance; environmental and social reporting quality; board diversity

\section{Introduction}

Corporate reputation is companies' most valuable asset as it can position them to gain a better competitive advantage [1], leading to more sustainable performance [2,3]. Highly reputable companies enjoy a privileged market position because they have better access to resources on more favourable terms [4]. A study by Deloitte (2014) [5] mentioned that 87 per cent of the global executives surveyed rated the corporate reputation risk as more important than any other business risks.

Therefore, it is unsurprising that studies on corporate reputation are receiving greater attention from scholars and practitioners [6,7]. Due to its multidisciplinary perspectives, corporate reputation has been defined in various disciplines. In the field of economics, corporate reputation is considered a reflection of companies' past actions, which indicate companies' possible future financial performances to stakeholders [8]. In strategic management, corporate reputation is viewed as a unique, intangible asset that is hard to imitate [9], representing the collective impression that multiple stakeholders have about a company [10]. In sociology, corporate reputation is treated as a social phenomenon, comprised of "collective agreement about what the public knows about an actor" [10], and in the field of accounting, corporate reputation is referred to as an intangible asset that is similar to goodwill [11]. This study conceptualised corporate reputation by referring to the 
definition in the economics and strategic management fields, incorporating a combination of both economic and social performance, and the perceptions of key stakeholders on these performance [12]. This definition aligns with that of Waddock (2000) [13], who argued that reputation is the perceived capacity of companies to meet stakeholders' expectations. It is often conceptualised collectively as perceptions, attitudes and stakeholders' esteem [14].

Past studies demonstrated that companies with positive reputations are preferred by stakeholders and incur lower contracting and monitoring costs [15-17]. Corporate reputation is developed by the stakeholders' knowledge of the company's character, ability, products, services and behaviours [18]. Roberts and Dowling (2002) [2] argued that "the development of good reputation takes considerable time, and depends on companies making stable and consistent investments over time". Hence, corporate reputation is not easy to replicate or imitate by competitors $[19,20]$. Therefore, managing corporate reputation is an important element of business strategy that helps companies build and sustain a competitive advantage to improve corporate performance [2,21,22].

Corporate governance mechanisms have an important role in creating a better corporate image and reputation and strategizing business directions [23]. In this respect, the new Malaysia Code on Corporate Governance (MCCG 2017) emphasised that board members must possess an appropriate combination of skills, knowledge, experience and independent elements that match the objectives and strategic goals of the company. Diversity among board members offers greater depth and breadth in terms of competencies and skills compared to non-diverse boards. Studies by Radbourne (2003) [24] and Musteen et al., (2010) [25] indicated that effective corporate governance with specific board characteristics could influence corporate reputation. This is further supported by Bravo et al., (2015) [26] and Bear et al., (2010) [27] who reported that board independence and board gender are positively associated with the level of corporate reputation.

Additionally, corporate environmental and social reporting quality can be an important instrument to improve corporate reputation [28,29]. Previous studies have shown that CSR reporting not only signals companies' commitment on social responsibility issues, but that it is also increasingly regarded as a means of enhancing corporate reputation [30-34]. Thus, by providing stakeholders with high quality in environmental and social reporting, the company can minimise asymmetric information, which improves stakeholders' understanding of the company's activities [35]. The MCCG (2012), Principle 7, Recommendation 7.1, emphasises the need for timely and high-quality disclosures by publicly listed companies in Malaysia. The Code suggests that boards should ensure companies have appropriate corporate disclosure policies and procedures. Furthermore, the regulations introduced by Bursa Malaysia in the Sustainability Reporting Guidelines in 2018, under Listing Requirements Paragraph 6.1, Practice Note 9, also emphasise that all listed companies must ensure that their sustainability statements contain information that is balanced, comparable and meaningful.

Therefore, it can be deduced that companies with effective corporate governance (having the right mixed of board members with certain characteristics) can be expected to influence the management to provide high quality environmental and social reporting and enhance stakeholders' confidence and eventually the company's reputation. Despite the importance of environmental and social reporting as a mediator variable between corporate governance effectiveness and corporate reputation, to the authors' knowledge, no studies have investigated this issue. Therefore, this study bridges research gaps by investigating the possible mediating effect of environmental and social reporting quality between these variables. The specific objectives of the study are to investigate the effects of corporate governance and environmental and social reporting on corporate reputation. Additionally, this study examines the role of environmental and social reporting on the relationship between corporate governance and corporate reputation.

The results show that corporate governance effectiveness and environmental and social reporting quality have positive relationships with corporate reputation. Furthermore, 
environmental and social reporting quality mediates the relationship between corporate governance and corporate reputation.

The research findings may be useful to business leaders in corporate strategy formulation. The findings indicate that implementing effective corporate governance mechanisms and disclosing high quality environmental and social reporting reduces information uncertainty and increases stakeholders' confidence, which eventually lead to better corporate reputation. Specifically, the findings can help companies to establish criteria and qualifications for the appointment of new board members. The members must have the right combination of skills, knowledge, experience and independent elements that enable them to make decisions for companies' environmental and social reporting practices that can enhance corporate reputation.

\section{Theory, Literature Review and Hypotheses Development}

\subsection{Theoretical Background}

This study used agency theory to examine the relationship between corporate governance, environmental and social reporting quality and corporate reputation Agency theory is concerned with the agency relationship in which one party (the principals) delegate a task to another (the agents), who carry it out. The principal uses monitoring tools to mitigate any opportunistic behaviours of the agent and to implement incentive systems to reduce the divergence of interests between the principal and agent [36]. One of the monitoring tools is the implementation of effective corporate governance mechanisms by aligning companies' conduct with the interests of stakeholders and ensuring transparency in companies' actions [37]. In this regard, the board of directors, who act on behalf of shareholders, has the role of influencing management to provide relevant information to fulfil stakeholders' needs [38]. In this context, a company that provides better quality environmental and social information can reduce information asymmetry. Corporate environmental and social reporting quality can be an important instrument to improve corporate reputation $[28,29]$. However, for the board to effectively carry out its monitoring task, it must possess specific characteristics [36].

\subsection{Corporate Governance}

Corporate governance has been described in several ways by researchers. Cadbury (1992) [39] views corporate governance as the system by which businesses are directed and managed, whereas [37] defines corporate governance as a system of structural, procedural, and cultural protections intended to guarantee that a company operates in the best long-term interests of its stakeholders. Investors prefer to invest their money into companies that have better governance practices [40]. Previous research has shown that the characteristics of the board of directors are critical to improving corporate governance procedures $[26,41,42]$. This study, unlike previous studies that concentrated on a few specific board director characteristics, examined a more comprehensive set of characteristics of boards of directors, such as the board size and board independence, board meetings, board diversity and audit committee characteristics. Currently, board diversity is regarded as one of the most vital aspects of a successful board structure [43,44]. Previous research has suggested that board diversity may help with managerial oversight and control [45], as well as enhancing board interactions and improving board procedures [46]. This implies that the more diverse the board, the more effective their decisions will be [47].

\subsection{Corporate Governance and Corporate Reputation}

Corporate governance mechanisms are established to protect investors by monitoring possible opportunistic managerial behaviour, increasing companies' value and confidence in capital markets [26]. In particular, independent directors are more likely to protect shareholders' interests. A study by Bravo et al., (2015) [26] reported that highly reputable companies have higher percentages of independent directors. Moreover, independent directors are professionals with incentives to defend or build their own reputations as 
monitoring experts [48]. Hence, it is expected that their presence on a board may help companies to improve their public image [49].

In addition to board independence, a diverse board membership provides the essential tools that enhance the effectiveness of boardroom discussion and decision making [50]. A board that combines individual talent, views, diversity and personalities produces a stronger management team [51] and improves corporate performance and reputation [27,52,53]. Bravo et al., (2015) [26] also discovered that most reputable companies are more likely to have more female directors on their boards. From an agency theory perspective, women directors often bring in a fresh perspective to complex issues, improving strategy formulation and decision-making processes [54]. This can also improve companies' reputation, as female board members can influence perceptions of corporate effectiveness [55].

Thus, good corporate governance with desirable board characteristics can be expected to ensure better corporate strategic development and effectiveness. This leads to better longterm performance, contributing to corporate reputation [24]. Additionally, a company with good corporate governance practices can raise funds for investment at a lower cost [56], thereby strengthening its corporate reputation. Contrary to expectations, Lu et al. [57] found no significant relationship between reputation and variables of board characteristics, i.e., board size, ownership and committees. Hence, these mixed findings provided the authors with an opportunity to further explore this issue [25,26,57].

According to agency theory, a company with good governance will be able to minimise agency conflict and achieve better corporate outcomes. Therefore, companies with good corporate governance are more reputable and recognised by stakeholders. Thus, the first hypothesis is as follows:

Hypothesis 1 (H1): There is a positive relationship between corporate governance and corporate reputation.

\subsection{Environmental and Social Reporting Quality and Corporate Reputation}

Corporate environmental and social reporting helps to build good reputations and also can be used as a mechanism to display a positive image to stakeholders [58-61]. Extensive evidence demonstrates that companies attempt to manage reputational risks by providing environmental and social reports [62,63]. Additionally, a considerable number of studies have shown that companies benefit from engaging in environmental and social reporting not only by obtaining favourable consumer awareness, attitudes and a sense of attachment but also by building a positive long-term corporate image [64-67].

McWilliams and Siegel (2006) [68] indicated that corporate social responsibility activity is a form of strategic investment initiative and that environmental and social reporting contributes to the competitive advantages of a company [69,70]. Toms (2002) [28] and De Los Ríos and Ruiz (2012) [29] found that information on environmental issues is positively correlated with a better corporate reputation.

From the Malaysian perspective, Abdullah and Abdul Aziz (2013) [71] analysed whether corporate social responsibility initiatives by Malaysian corporations influenced corporate reputation, corporate culture and legitimacy. Data for this study were collected through questionnaires. The results indicated the significant impact of all dimensions of environmental and social activities on corporate reputation, implying that moral, discretionary and relational constructs influence corporate reputation. More specifically, the results clearly demonstrated that companies wishing to foster and sustain their corporate reputation must exercise moral obligations by giving full support to employees and involving them directly in charitable activities to build positive relationships with stakeholders.

The present study proposes that environmental and social reporting quality can be a potentially powerful medium that companies might use to influence stakeholder perceptions. The literature suggests that the quality of information influences corporate reputation more significantly than the mere reporting of large amounts of quantitative 
or qualitative information [28,29]. Toms (2002) [28] has revealed how information on environmental issues is positively correlated with a better reputation.

The signalling theory proposes that companies can build, maintain and defend their reputation by providing high-quality environmental and social reporting. Additionally, the quality of reporting can serve as a strategic signal to capital markets to reduce the information asymmetry that arises between managers and stakeholders [7]. Spence (1974) [72] also claims that signalling theory is used to describe behaviour when two parties have different information. Thus, companies that engage in environmental and social activities and report those activities to the public may provide a strategy signal to stakeholders that will eventually improve corporate reputation. Therefore, the second hypothesis can be stated as follows:

Hypothesis $\mathbf{2}$ (H2): There is a positive relationship between environmental and social reporting quality and corporate reputation.

\subsection{Mediating Role of Environmental and Social Reporting Quality on the Relationship between Corporate Governance and Corporate Reputation}

Based on the previous discussion, $\mathrm{H} 1$ of this study predicts a direct and positive relationship between corporate governance and corporate reputation. Additionally, $\mathrm{H} 2$ also predicts a direct and positive relationship between environmental and social reporting quality with corporate reputation $[57,69,73]$. Therefore, this study anticipates that environmental and social reporting quality could mediate the relationship between corporate governance and corporate reputation. In other words, effective corporate governance leads to higher quality environmental and social reporting, which eventually improves corporate reputation. However, no previous study has attempted to include environmental and social reporting quality as an important variable in these relationships.

The mediating effect of environmental and social disclosure among the 500 leading green US companies has been studied by Wang and Sarkis (2017) [74], who investigated the role that disclosure had on the relationship between corporate governance and financial performance. Their findings suggest that environmental and social reporting fully mediates the relationship between corporate governance and financial performance. A study by Zhou (2014) [75] of Chinese family companies revealed that environmental and social reporting partially mediates the relationship between family commitment and the organisational identification felt by employees. Sial and Zheng [76] also examined the mediating impact of environmental and social reporting on the relationship between board gender diversity and the financial performance of Chinese listed companies. The results showed that environmental and social reporting fully mediates the relationship between boardroom gender diversity and firm performance.

According to agency theory, the primary function of corporate governance is to monitor and control management [77]. The theory argues that boards of directors protect shareholders' interests in order to reduce agency conflicts $[77,78]$ and ensure more beneficial outcomes for companies. One potential outcome is the quality of environmental and social reporting. Effective corporate governance monitors and controls managers so that the quality of their environmental and social reporting improves, which reduces agency costs and, thus, contributes to companies' corporate reputations. Bear and Rahman [27] investigated the mediating effect of social disclosure on the relationship between corporate governance and corporate reputation using a sample of US companies. The findings indicated that social disclosure mediates the relationship between female board members and corporate reputation. However, these results cannot be generalised across other industries as the sample comprised only major healthcare companies [27]. Hence, this study bridges these research gaps by examining the effect of environmental and social reporting quality in other industrial sectors. The outcomes of this study will highlight the importance of environmental and social reporting towards improving corporate reputation. Hence, hypothesis $\mathrm{H} 3$ can be stated as follows: 
Hypothesis 3 (H3): Environmental and social reporting quality mediates the relationship between corporate governance and corporate reputation.

\section{Research Methodology}

This study used secondary data collected from multiple sources, such as the Thomson Data Stream database, the Brand Finance website, the Google advanced research function, company websites and the annual reports of Malaysian publicly listed firms. The period of the study was from 2017 to 2018, immediately after the MCCG 2017 was revised and implemented. Two-year periods were specifically chosen because the proposed draft MCCG 2017 had been disseminated to companies about six months earlier (June 2016) to ensure that companies had sufficient time to implement new guidelines. The MCCG 2017 requires companies to revise the composition of their board members so that they contain an appropriate mix of talents, knowledge, experience and independent elements that can match the company objectives and strategic goals.

\subsection{Population and Sample Selection}

The population of this study consisted of all the companies listed on Bursa Malaysia as of 31 December 2018. Companies from the financial, banking, insurance, trust, closed-end fund and securities sectors were excluded since they are subject to different rules and regulations, which may have influenced the nature of the data collected and the study results [79]. This study also excluded companies from two industries, the mining and hotel sectors, as fewer than five companies were listed in these industries. As a result, 745 companies from 7 industries were considered as the research population. The seven industries were (1) consumer products, (2) industrial products, (3) construction, (4) trading and services, (5) properties, (6) plantation and (7) technology. Table 1 summarises the sampling frame for this study.

Table 1. Sampling frame.

\begin{tabular}{lc}
\hline \multicolumn{1}{c}{ Population } & Total \\
\hline Number of companies listed on Bursa Malaysia in 2018 & 915 \\
Finance-related companies excluded & 165 \\
Mining and hotel companies excluded & 5 \\
\hline Number of companies & 745 \\
\hline
\end{tabular}

The sampling method used in this study was stratified random sampling. This method segregates the population based on the type of industry [80]. As recommended in [81], if the target population is around 750 companies, the study should have a sample size of 254 . Therefore, the sample size of this study consisted of 306 companies for the two-year period from 2017 to 2018, as shown in Table 2.

Table 2. Population and sample selection.

\begin{tabular}{clccc}
\hline & \multicolumn{1}{c}{ Industry } & Population & Samples & \% of Samples \\
\hline 1 & Consumer products & 125 & 50 & 16.33 \\
2 & Industrial products & 221 & 90 & 29.41 \\
3 & Construction & 46 & 20 & 6.54 \\
4 & Trading and services & 188 & 78 & 25.49 \\
5 & Properties & 94 & 38 & 12.42 \\
6 & Plantation & 41 & 16 & 5.23 \\
7 & Technology industries & 30 & 14 & 4.58 \\
\hline
\end{tabular}




\subsection{Measurement of Variables}

\subsubsection{Dependent Variable}

The dependent variable of this study was corporate reputation, which was measured according to five dimensions: commitment to stakeholders, financial performance [3], media exposure [3], brand value [82] and awards [83,84]. The study operationalized and transformed the five dimensions of corporate reputation into an index with a maximum score of 7 . The detailed measurements of the index are presented in Table 3.

Table 3. The measurement of corporate reputation index.

\begin{tabular}{|c|c|c|c|c|}
\hline No. & Variable & & Measurement & Index Scoring \\
\hline \multirow[t]{2}{*}{1} & \multirow[t]{2}{*}{$\begin{array}{l}\text { Commitment to } \\
\text { stakeholders }\end{array}$} & (a) & $\begin{array}{l}\text { Ordinal value from } 0 \text { (no stakeholder engagement) to } 4 \\
\text { (maximum stakeholder engagement) }\end{array}$ & $\begin{array}{l}\text { " } 1 \text { " if the value is above the sample average } \\
\text { score and " } 0 \text { " otherwise }\end{array}$ \\
\hline & & (b) & Whether company has a CSR/ethics committee & $\begin{array}{l}\text { " } 1 \text { " if a company has a CSR/ethics } \\
\text { committee and " } 0 \text { " otherwise }\end{array}$ \\
\hline \multirow[t]{2}{*}{2} & \multirow[t]{2}{*}{$\begin{array}{l}\text { Financial } \\
\text { performance }\end{array}$} & (a) & Return on equity $(\mathrm{ROE})=$ net income/shareholders' equity & $\begin{array}{l}\text { " } 1 \text { " if the ROE is above the industry average } \\
\text { and " } 0 \text { " otherwise }\end{array}$ \\
\hline & & (b) & Share return $=\left(\right.$ price $_{t}-$ price $\left._{t-1}\right) /$ price $_{t-1}$ & $\begin{array}{l}\text { " } 1 \text { " if the share return is above the industry } \\
\text { average and " } 0 \text { " otherwise }\end{array}$ \\
\hline 3 & Media exposure & \multicolumn{2}{|r|}{ The difference between positive and negative reporting } & $\begin{array}{l}\text { " } 1 \text { " if the positive reporting is more than the } \\
\text { negative reporting and " } 0 \text { " otherwise }\end{array}$ \\
\hline 4 & Brand value & \multicolumn{2}{|r|}{ Whether the company is listed in Malaysian Top 100 Brands } & " 1 " if a company is listed and " 0 " otherwise \\
\hline 5 & Award & \multicolumn{2}{|r|}{ Whether the company has received any national/international awards } & $\begin{array}{l}\text { " } 1 \text { " if the company received awards and } \\
\text { " } 0 \text { " otherwise }\end{array}$ \\
\hline
\end{tabular}

This study collected information on company stakeholder engagement from annual reports. The financial performance data were gathered from the Thompson DataStream database. Additionally, this study used the advanced Google research function tool to collect data on media exposure $[85,86]$. In this study, the media exposure was limited only to reporting found in The Edge Malaysia, a leading business newspaper in Malaysia. A pilot study was conducted, the results of which confirmed that more company business activities were reported in The Edge Malaysia than in any other newspaper publication. This study extracted brand value information from the Brand Finance website (https: //brandfinance.com/offices/malaysia (accessed on 20 April 2020)) to gather data on the sample companies that were listed as the Malaysian Top 100 Brands. Brand Finance is the world's leading brand valuation consultancy, with offices in over 15 countries. It is also one of the world's first companies to be accredited to provide ISO 10668-compliant brand valuations. The ISO 10668 global standard provides a consistent, reliable approach to brand valuation that emphasizes transparency and objectivity. Furthermore, information on awards received was gathered from company annual reports. Examples of the awards received were for Industry Excellence, Investor Relations, Best Company to Work For, Best Project and Social Media Excellence.

\subsubsection{Independent Variable}

The independent variable of this study was corporate governance effectiveness. This was measured based on the scores of a composite index consisting of ten board and four audit committee characteristics with a maximum score of 14 . Studies on the effectiveness of corporate board effectiveness argue that the measurement of this feature should capture the characteristics of individual board members so that these characteristics collectively form a more comprehensive means of measuring board effectiveness [87]. Similarly, studies on audit committee effectiveness also recommend the use of a composite index to evaluate a committee's effectiveness $[88,89]$. Thus, based on these arguments, this study developed a corporate governance effectiveness index, as outlined in Table 4. 
Table 4. The measurement of corporate governance index.

\begin{tabular}{|c|c|c|c|}
\hline & Independent Variable & Score & Index \\
\hline A & Board of directors & & \\
\hline 1 & Board size & " 1 " if the number of board members is between $5-14$ and " 0 " otherwise & 1 \\
\hline 2 & Board independence & " 1 " if the number of independent board members is at least half of the board and " 0 " otherwise & 1 \\
\hline 3 & Board meetings & " 1 " if the number of board meetings held during the year is four times or more and " 0 " otherwise & 1 \\
\hline 4 & Board ethnicity & " 1 " if board has at least two different ethnic groups and " 0 " otherwise & 1 \\
\hline 5 & Board gender & " 1 " if the board comprises male and female directors and " 0 " otherwise & 1 \\
\hline 6 & Foreign director & " 1 " if the board comprises at least one foreign director and "0" otherwise & 1 \\
\hline 7 & Board educational level & " 1 " if the board comprises at least two different educational levels and " 0 " otherwise & 1 \\
\hline 8 & Board educational background & " 1 " if the board comprises at least two different educational backgrounds and " 0 " otherwise & 1 \\
\hline 9 & Board age & $\begin{array}{l}\text { " } 1 \text { " if the board comprises of all categories of age (that is, it consists of younger, middle-aged } \\
\text { and older members) and " } 0 \text { " otherwise }\end{array}$ & 1 \\
\hline \multirow[t]{2}{*}{10} & Board tenure & " 1 " if the board comprises at least two categories of years of service and "0" otherwise & 1 \\
\hline & $\begin{array}{l}\text { Sub-index score } \\
\text { Audit committee }\end{array}$ & & 10 \\
\hline 1 & Audit committee size & "1" if audit committees are comprised of at least three members and "0" otherwise & 1 \\
\hline 2 & Audit committee independence & " 1 " if audit committees are comprised solely of independent members and " 0 " otherwise & 1 \\
\hline 3 & Audit committee meetings & $\begin{array}{l}\text { " } 1 \text { " if the number of audit committee meetings held during the year is at least four and } \\
\text { " } 0 \text { " otherwise }\end{array}$ & 1 \\
\hline \multirow[t]{3}{*}{4} & Audit committee financial literacy & $\begin{array}{l}\text { " } 1 \text { " if all members of the audit committee have a financial education background and } \\
\text { " } 0 \text { " otherwise }\end{array}$ & 1 \\
\hline & Sub-index score & & 4 \\
\hline & Total score & & 14 \\
\hline
\end{tabular}

\subsubsection{Mediating Variable}

The mediating variable of this study was environmental and social reporting quality (ESRQ). This study employed content analysis to collect information on ESRQ from company annual reports. As presented in Table 5, the ESRQ comprises four dimensions: employee relations, community involvement, products and environment.

Table 5. Category and measurement of environmental and social reporting.

\begin{tabular}{clcc}
\hline \multicolumn{1}{c}{ Category } & No. of Items & Maximum Score \\
\hline 1 & Employee relations & 6 & 18 \\
2 & Community involvement & 6 & 18 \\
3 & Products & 4 & 12 \\
4 & Environment & 4 & 12 \\
\hline & Total Score & & 60 \\
\hline
\end{tabular}

Following [83,90,91], the ESRQ score was calculated by assigning reporting into four classifications as follows:

(1) A score of "3" was given for a specific quantitative disclosure. The disclosure had to contain financial information;

(2) A score of "2" was given for a specific qualitative disclosure. This is a non-quantitative disclosure with specific CSR information;

(3) A score of "1" was given for CSR-related general disclosure;

(4) A score of "0" was given if companies did not disclose any kind of CSR information.

In order to ensure the reliability of these disclosure items, a Cronbach's alpha reliability test was performed. The results showed that the disclosure items were highly reliable, as the value $\alpha=0.89$. The general rule of thumb is that a Cronbach's alpha value of more than 0.70 is considered acceptable, as that value reflects that reliability measurement of the four disclosure items' dimensions [92].

This study also incorporated five control variables that have been proven in past studies to influence corporate reputation. They were company size, leverage, growth, risk and profitability. Larger companies are strong indicators of corporate reputation $[25,26,93,94]$. Company size was measured based on the value of the natural logarithm of its total assets. 
Leverage has traditionally been used as a proxy for financial risk, which can negatively affect corporate reputation [95]. This study measured company leverage as total debts divided by total assets. The growth prospects of the companies were measured by Tobin's $\mathrm{Q}$ ratio. The ratio was calculated by dividing the company market value of equity by the book value of equity $[96,97]$. Risk was measured by the companies' systematic risk (beta). The beta coefficient is calculated by dividing the covariance of the stock return versus the market return by the market variance. Lastly, the profitability was measured using return on assets (ROA) which was calculated by dividing net income by average total assets.

\subsection{Empirical Research Model}

This study employed multiple regression analysis to test all the hypotheses [98-102]. This study relied on ordinary least-squares regression because corporate governance data are subject to the stickiness issue, whereby the variation in panel data is non-existent or extremely minimal over time [103]. Thus, to test the hypotheses, the study employed these regression models as follows:

Model 1: This model was used to test $\mathrm{H} 1$. The dependent variable was $\mathrm{CR}$, while the independent variable was CG, and there were five control variables.

$$
\mathrm{CR}=\beta_{0}+\beta_{1} \mathrm{CG}+\beta_{2} \mathrm{SIZE}+\beta_{3} \mathrm{LEV}+\beta_{4} \mathrm{MTB}+\beta_{5} \mathrm{ROA}+\beta_{6} \mathrm{RISK}+\varepsilon_{\mathrm{it}}
$$

Model 2: This model was used to test $\mathrm{H} 2$. The dependent variable was $\mathrm{CR}$ and the independent variable was ESRQ, and there were five control variables.

$$
\mathrm{CR}=\beta_{0}+\beta_{1} \mathrm{ESRQ}+\beta_{2} \mathrm{SIZE}+\beta_{3} \mathrm{LEV}+\beta_{4} \mathrm{MTB}+\beta_{5} \mathrm{ROA}+\beta_{6} \mathrm{RISK}+\varepsilon_{\mathrm{it}}
$$

Model 3: This model was used to examine H3; that is, whether the ESRQ plays a mediating role in the association between CG and CR. This study used the following procedures to test the mediation effect [104]:

(1) The direct relationship between CR (dependent variable) and CG effectiveness (independent variable) had to be significant;

(2) The direct relationship between CG effectiveness (independent variable) and ESRQ (mediating variable) had to be significant;

(3) The direct relationship between ESRQ (mediating variable) and CR (dependent variable) had to be significant;

(4) The direct relationship between CG effectiveness (independent variable) and ESRQ (mediating variable) together with CR (dependent variable) had to be significant.

$$
\mathrm{CR}=\beta_{0}+\beta_{1} \mathrm{CG}+\beta_{2} \mathrm{ESRQ}+\beta_{3} \mathrm{SIZE}+\beta_{4} \mathrm{LEV}+\beta_{5} \mathrm{MTB}+\beta_{6} \mathrm{ROA}+\beta_{7} \mathrm{RISK}+\varepsilon_{\mathrm{it}}
$$

\section{Results and Discussion}

\subsection{Descriptive Information for the Corporate Reputation (CR) Variable}

As discussed, this study developed a CR index based on five dimensions: commitment to stakeholders, financial performance, media exposure, brand value and awards; the maximum score was 7. Table 6 presents descriptive information about the variable.

Panel A of Table 6 presents the CR scoring based on the five dimensions. The positive mean for the media exposure indicates that the sample companies received more positive than negative media coverage. Additionally, on average, the sample companies received only one award in 2017 and 2018.

Panel B of Table 6 reports the mean, minimum and maximum values of the index scores. The mean score was 2.70 in 2017 and it increased to 3.39 in 2018. The overall mean value for the $C R$ index was 3.04, with minimum and maximum values of 0.00 and 7.00 , respectively. 
Table 6. Descriptive information for the corporate reputation dimensions $(n=306)$.

\begin{tabular}{|c|c|c|c|c|c|}
\hline \multicolumn{6}{|c|}{ Panel A: Dimensions of Corporate Reputation } \\
\hline No. & Dimensions & Mean & Std Dev & Min & $\operatorname{Max}$ \\
\hline \multirow[t]{3}{*}{1} & Commitment to stakeholders: & & & & \\
\hline & (a) Stakeholder engagements & 1.51 & 1.48 & 0.00 & 4.00 \\
\hline & (b) CSR committee & 0.59 & 0.49 & 0.00 & 1.00 \\
\hline \multirow[t]{3}{*}{2} & Financial performance: & & & & \\
\hline & (a) ROE & 0.39 & 23.10 & -230.43 & 35.84 \\
\hline & (b) Share return & 0.02 & 0.56 & -0.78 & 7.29 \\
\hline 3 & Media exposure & 4.73 & 6.54 & -4.00 & 40.00 \\
\hline 4 & Brand value & 0.09 & 0.30 & 0.00 & 1.00 \\
\hline 5 & Awards & 0.96 & 2.41 & 0.00 & 20.00 \\
\hline \multicolumn{6}{|c|}{ Panel B: Corporate Reputation Index } \\
\hline & Score & Mean & Std Dev & Min & $\operatorname{Max}$ \\
\hline \multicolumn{2}{|c|}{ Year $2017(\mathrm{~N}=153)$} & 2.70 & 1.67 & 0.00 & 7.00 \\
\hline \multicolumn{2}{|c|}{ Year $2018(\mathrm{~N}=153)$} & 3.39 & 1.59 & 0.00 & 7.00 \\
\hline \multicolumn{2}{|c|}{ Overall $(\mathrm{N}=306)$} & 3.04 & 1.66 & 0.00 & 7.00 \\
\hline
\end{tabular}

\subsection{Descriptive Information for Corporate Governance (CG) Variables}

Table 7 shows the descriptive information for the corporate governance variable. Panel A shows that the mean score for the board size was 7 members, with a minimum of 4 members and a maximum of 15 members on the boards. This average is consistent with prior studies $[105,106]$. The mean score for board independence was 49.21 per cent, with a minimum of 20 per cent and a maximum of 100 per cent. The average score almost complies with the recommendation of the MCCG 2017, which requires that independent directors must comprise at least 50 per cent of a company's board membership.

Table 7. Descriptive statistics for corporate governance variables $(\mathrm{N}=306)$.

\begin{tabular}{|c|c|c|c|c|c|}
\hline \multicolumn{6}{|c|}{ Panel A: Descriptive Information for Board and Audit Committee Characteristics } \\
\hline No. & Characteristics & Mean & Std Dev & Min & Max \\
\hline 1 & Board size & 7.08 & 1.79 & 4.00 & 15.00 \\
\hline 2 & Board independence $(\%)$ & 49.21 & 13.39 & 20.00 & 100.00 \\
\hline 3 & Female director $(\%)$ & 13.85 & 12.62 & 0.00 & 60.00 \\
\hline 4 & Foreign director (\%) & 6.23 & 15.00 & 0.00 & 100.00 \\
\hline 5 & Board ethnicity & 2.06 & 0.73 & 0.00 & 4.00 \\
\hline 6 & Board meetings & 5.51 & 1.92 & 4.00 & 19.00 \\
\hline 7 & Audit committee size & 3.22 & 0.54 & 2.00 & 7.00 \\
\hline 8 & Audit committee independence (\%) & 90.00 & 0.59 & 50.00 & 100.00 \\
\hline 9 & Audit committee meetings & 5.06 & 1.03 & 4.00 & 11.00 \\
\hline \multicolumn{6}{|c|}{ Panel B: Corporate Governance Index } \\
\hline & Year & Mean & Std Dev & Min & Max \\
\hline & Year $2017(\mathrm{~N}=153)$ & 10.01 & 1.26 & 7.00 & 14.00 \\
\hline & Year $2018(\mathrm{~N}=153)$ & 10.08 & 1.39 & 7.00 & 14.00 \\
\hline & Overall $(\mathrm{N}=306)$ & 10.05 & 1.33 & 7.00 & 14.00 \\
\hline
\end{tabular}

The mean score for female directors on boards was 13.85 per cent, ranging from 0 to 60 per cent. The percentage is slightly higher than that found by Katmon et al., (2017) [106], who reported that the percentage of female directors on boards was only 8.4 per cent, with a minimum of 0 and a maximum of 40 per cent. These results indicate that board gender diversity has been progressing in the Malaysian business environment, albeit very slowly.

The mean score for the number of foreign directors on boards was 6.23 per cent. The average is lower than that mentioned in the studies by Katmon et al., (2017) [106] and 
Ibrahim and Hanefah (2016) [107], who reported 7 per cent and 10 per cent for the numbers of foreign directors on boards, respectively. The maximum of 100 per cent indicates there were sample companies whose boards consisted of only foreign directors. The mean for the board ethnicity was 2.06, with a minimum of 0 and a maximum of 4 . The mean of 2.06 indicates that, on average, the sample company boards consisted of at least two different ethnicities. The mean score for board meeting frequency was 5.51 times. The minimum for the board meeting frequency was 4 times and the maximum was 19 times per year.

The mean size of the audit committees was 3.22, comparable with the means of 3.24 in Katmon et al., (2017) [106] and 3.51 in Mohamad Nor et al., (2010) [108]. This finding is consistent with the Bursa Malaysia Listing Requirement, which states that audit committees must have a minimum of three members. The mean percentage for the audit committee independence was 90 per cent, with a minimum of 50 per cent and a maximum of 100 per cent. This result is not consistent with the requirement in the MCCG 2017, which requires 100 per cent of the audit committee members to be independent directors. The mean number of audit committee meetings was 5.51 per year. The MCCG 2017 requires that audit committee meetings must be held at least four times a year.

Panel B displays the corporate governance index for 2017 and 2018 and the overall scores. The data reveal that the average corporate governance index increased from 10.01 (2017) to 10.08 (2018), with a minimum of 7 and a maximum of 14 . The overall score for the corporate governance index was 10.05 .

\subsection{Descriptive Information for Environmental and Social Reporting Quality (ESRQ)}

This study measured the level of ESRQ based on 4 disclosure dimensions, comprising 20 items with a maximum score of 60 . Table 8 shows that the average score for employee relations was 6.69 out of 18.00 , with a maximum score of 13.00 . The average for community involvement was 5.52 out of 18.00 , with a maximum score of 18.00 . In addition, the average for product was 4.82 out of 12.00 , with a maximum score of 10.00 , and the average for environment was 5.38 out of 12 , with a maximum score of 11.00 .

Table 8. Descriptive statistics for environmental and social reporting quality.

\begin{tabular}{|c|c|c|c|c|c|}
\hline \multicolumn{6}{|c|}{ Panel A: ESRQ Based on Specific Aspects } \\
\hline & Dimension & Mean & Std. Dev. & Min & Max \\
\hline 1 & Employee relations & 6.69 & 2.53 & 0.00 & 13.00 \\
\hline 2 & $\begin{array}{l}\text { Community } \\
\text { involvement }\end{array}$ & 5.25 & 3.90 & 0.00 & 18.00 \\
\hline 3 & Product & 4.82 & 3.15 & 0.00 & 10.00 \\
\hline 4 & Environment & 5.38 & 2.32 & 0.00 & 11.00 \\
\hline \multicolumn{6}{|c|}{ Panel B: ESRQ Based on Year } \\
\hline & & Mean & Std. Dev. & Min & Max \\
\hline & Year $2017(n=153)$ & 20.31 & 9.84 & 0.00 & 43.00 \\
\hline & Year $2018(n=153)$ & 23.97 & 8.50 & 2.00 & 43.00 \\
\hline & Overall $(n=306)$ & 22.14 & 9.36 & 0.00 & 43.00 \\
\hline
\end{tabular}

Panel B in Table 8 shows that the overall mean ESRQ score was 22.14, with a maximum score of only 43.00. The table also shows that ESRQ increased from 20.13 in 2017 to 23.97 in 2018.

\subsection{Regression Assumptions}

Multicollinearity is an essential assumption in regression analysis [92]. This study applied the variance inflation factor (VIF) to test multicollinearity and tolerance (1/VIF) in order to investigate collinearity issues. According to Gujarati (2003) [92], a VIF value of less than 10 and a tolerance value of more than 0.1 indicate no multicollinearity issues. 
Table 9 shows that the VIF values were less than 10 and the tolerance values were more than 0.1 . Thus, the models specified in this study are less likely to suffer from these issues.

Table 9. VIF and tolerance values for independent variables.

\begin{tabular}{ccc}
\hline Variables & VIF & $\mathbf{1 / V I F}$ \\
\hline SIZE & 1.69 & 0.591435 \\
LEV & 1.42 & 0.701828 \\
ESRQ & 1.39 & 0.720903 \\
ROA & 1.37 & 0.730693 \\
RISK & 1.13 & 0.887361 \\
MTB & 1.10 & 0.907062 \\
CGI & 1.07 & 0.937636 \\
\hline
\end{tabular}

In order to assess the strength and direction of the association between corporate reputation and all other variables, the correlation coefficients between the variables were obtained using the Pearson correlation test. The results could also be used to test multicollinearity [92]. Table 10 shows that none of the independent variables had a correlation coefficient of more than 0.8 when set against any other independent variables. We observed that the highest degree of correlation existed between CR and SIZE (0.581). Thus, there were no multicollinearity issues among the independent variables in this study.

Table 10. Correlation matrix.

\begin{tabular}{|c|c|c|c|c|c|c|c|c|}
\hline Variables & CR & CGI & ESRQ & SIZE & LEV & МТВ & ROA & RISK \\
\hline CR & 1 & & & & & & & \\
\hline CGI & $0.177^{* * *}$ & 1 & & & & & & \\
\hline ESRQ & $0.576^{* * *}$ & $0.192^{* * *}$ & 1 & & & & & \\
\hline SIZE & $0.581^{* * *}$ & $0.125^{* *}$ & $0.489^{* * *}$ & 1 & & & & \\
\hline LEV & $0.149^{* * *}$ & -0.040 & 0.077 & $0.327^{* * *}$ & 1 & & & \\
\hline MTB & $0.255^{* * *}$ & 0.080 & $0.199 * * *$ & 0.194 & $-0.011^{* * *}$ & 1 & & \\
\hline $\mathrm{ROA}$ & $0.250^{* * *}$ & $0.158^{* * *}$ & $0.159^{* * *}$ & $0.214^{* * *}$ & $-0.338^{* * *}$ & $0.242 * * *$ & 1 & \\
\hline RISK & $0.234^{* * *}$ & -0.053 & $0.195^{* * *}$ & $0.279^{* * *}$ & $0.222 * * *$ & 0.016 & -0.019 & 1 \\
\hline
\end{tabular}

${ }^{* * *} p<0.01 * * p<0.05 . \mathrm{CR}=$ corporate reputation, $\mathrm{CGI}=$ corporate governance index, $\mathrm{ESRQ}=$ environmental and social reporting quality, SIZE $=$ total assets, $\mathrm{LEV}=$ leverage (total debts $/$ total assets), $\mathrm{MTB}=$ market to book value, ROA = return on assets, RISK = beta .

\subsection{Testing of Hypothesis}

As discussed, three hypotheses were tested in the study. The results of all the regression analyses used to test these hypotheses are presented in Table 11.

Table 11. Results of regression analyses.

\begin{tabular}{ccccc}
\hline Variables & CR & CR & ESRQ & CR \\
\hline & Model 1 & Model 2 & Model 3 & Model 4 \\
\hline Constant & $-0.848^{* * *}$ & $-0.533^{* * *}$ & $-0.435^{* * *}$ & $-0.613^{* * *}$ \\
& $(-6.820)$ & $(-5.530)$ & $(-4.920)$ & $(-5.120)$ \\
CG & $0.238^{* *}$ & & $0.213^{* *}$ & 0.122 \\
& $(2.050)$ & & $(2.590)$ & $(1.130)$ \\
ESRQ & & $0.552^{* * *}$ & & $0.540^{* * *}$ \\
SIZE & $0.078^{* * *}$ & $(7.420)$ & & $(7.180)$ \\
& $(9.200)$ & $\left(6.052^{* * *}\right.$ & $0.048^{* * *}$ & $0.052^{* * *}$ \\
LEV & 0.001 & 0.001 & $(7.950)$ & $(6.040)$ \\
& $(0.110)$ & $(0.770)$ & -0.001 & 0.001 \\
MTB & $0.032^{* *}$ & $0.232^{* *}$ & $(-1.600)$ & $(0.780)$ \\
& $(2.660)$ & $(2.060)$ & $0.017^{*}$ & $0.023^{* *}$ \\
ROA & $0.003^{*}$ & $0.003^{* *}$ & $(1.960)$ & $(2.050)$ \\
& & & -0.001 & $0.003^{* *}$ \\
\hline
\end{tabular}


Table 11. Cont.

\begin{tabular}{ccccc}
\hline Variables & CR & CR & ESRQ & CR \\
\hline & Model 1 & Model 2 & Model 3 & Model 4 \\
\hline RISK & $(1.950)$ & $(2.330)$ & $(-0.250)$ & $(2.210)$ \\
& $0.033^{* *}$ & 0.021 & $0.019 *$ & 0.022 \\
$\mathrm{R}^{2}$ & $(2.100)$ & $(1.430)$ & $(1.770)$ & $(1.520)$ \\
Adjusted $R^{2}$ & 0.385 & 0.473 & 0.279 & 0.476 \\
F-statistic & 0.373 & 0.460 & 0.2646 & 0.463 \\
Prob $>$ F & 31.270 & 44.880 & 19.290 & 38.680 \\
*** $p<0.01,{ }^{* *} p<0.05, * * 0.000$ & 0.000 & 0.000 \\
ESRQ $=$ environmental and social reporting quality, SIZE = total assets, LEV = leverage (total debts/total assets), \\
MTB = market to book value, ROA = return on assets, RISK = beta.
\end{tabular}

\subsubsection{Corporate Governance (CG) and Corporate Reputation (CR)}

Model 1 in Table 11 presents the regression analysis results used to test H1. Consistent with expectations, corporate governance is significantly and positively associated with corporate reputation $(\mathrm{B}=0.238, \mathrm{t}=2.050, p<0.05)$. The adjusted $\mathrm{R}^{2}$ for model 1 was 37.3 per cent, indicating that 37.3 per cent of the variation in CR was explained by a set of predictors in model 1. Therefore, $\mathrm{H} 1$ was accepted.

The findings suggest that companies with effective corporate governance have better corporate reputations. Effective corporate governance mechanisms are established to protect investors, maximise corporate value and increase confidence in capital markets [26]. A company's good reputation depends strongly on internal organisational support, such as the corporate board and the audit committee characteristics. Based on agency theory, effective board members can reduce agency conflicts and enhance companies' outcomes.

The findings support previous empirical studies $[24,25]$ that confirmed that corporate governance is positively and significantly associated with corporate reputation. Bravo et al., (2015) [26] also showed that directors' characteristics are associated with increased stakeholder confidence and a better company reputation.

\subsubsection{Environmental and Social Reporting Quality (ESRQ) and Corporate Reputation (CR)}

Table 11 also shows the results for the regression analysis used to test $\mathrm{H} 2$, which investigates the relationship between ESRQ and CR (model 2). Consistent with the predictions, there is a significant positive relationship between ESRQ and CR (B=0.552, $\mathrm{t}=7.420 . p<0.01$ ). The adjusted $\mathrm{R}^{2}$ is 46.33 per cent, $\mathrm{F}=44.88$ and $p<0.000$. Therefore, $\mathrm{H} 2$ was accepted.

The findings indicate that CR is the outcome of a company's actions and that CSR activities are among the most effective ways of building a good reputation [109]. Hence, a company's involvement in socially responsible activities enhances their image and reputation, as well as contributing to society's well-being. In addition, engaging in environmental and social activities improves stakeholder satisfaction and positively affects corporate reputation [110]. In other words, ESRQ helps companies to build a positive image among stakeholders.

The findings support prior studies that showed that when companies take part in environmental and social activities, this leads to the improvement of corporate reputation [34,57,111-114]. Bayoud and Kavanagh (2012) [115] also found that environmental and social reporting enhances corporate reputation and financial performance, attracts foreign investors and increases customer satisfaction and employee commitment. Therefore, companies should become involved with socially responsible activities to improve their reputation.

The findings of this study can be explained by signalling theory [28], which argues that companies engage in environmental and social reporting to signal their commitment to stakeholders [33]. We suggest that, by disclosing high-quality environmental and social reporting, stakeholders can better understand a company's overall activities, which 
thereby improves the company's reputation. This is further supported by Odriozola et al., (2015) [116], who found that companies that conduct social practices obtain better reputations. Thus, companies signal their environmental and social activities, which improves their value and reputation.

4.5.3. Mediating Role of Environmental and Social Reporting Quality (ESRQ) in the Relationship between Corporate Governance (CG) and Corporate Reputation (CR)

The third hypothesis, H3, investigates whether ESRQ mediates the relationship between CG and CR. To examine this hypothesis, this study followed the three-step procedure recommended by Barron and Kenny (1986) [104]. In the first step, the independent variable must be significantly associated with the dependent variable. The results of model 1 , as shown in Table 11, indicated that the independent variable, CG, was significantly associated with the dependent variable, $C R(B=0.238, t=2.050, p<0.05)$. Therefore, the results fulfilled the first requirement in the examination of this hypothesis.

In the second step, the independent variable must be significantly associated with the mediator variable. The result of model 3 (Table 11) also showed that the independent variable, $C G$, was significantly associated with the mediation variable, ESRQ $(B=0.213$, $\mathrm{t}=2.590, p<0.05$ ).

In the third step, the mediating variable (ESRQ) must be significantly associated with the dependent variable (CR) after controlling for the other independent variable (CG). Model 4 (Table 11) showed that the mediator variable, ESRQ, had a significant and positive association with the dependent variable, $\mathrm{CR}$, after including the effect of the other independent variable, $C G$, in the model $(B=0.540, t=7.180, p<0.001)$.

Thus, this study fulfilled the requirements of the three-step procedure for the mediation analysis, which indicated that ESRQ mediated the relationship between CG and CR. Table 12 summarises the results of the analysis.

Table 12. Summary of results for mediation analysis.

\begin{tabular}{ccccc}
\hline Steps & Dependent Variable & Independent Variables & Coefficient & Coefficient Value \\
\hline First step & CR & CG & Total effect (c) & $0.238^{* *}$ \\
Second step & ESRQ & CG & Indirect effect (a) & $0.213^{* *}$ \\
Third step & CR & ESRQ and CG & Indirect effect (b) & $0.540^{* * *}$ \\
& & & Direct effect (c') & 0.122 \\
\hline
\end{tabular}

${ }^{* * *} p<0.01,{ }^{* *} p<0.05$

The summary shown in Table 12 provides several explanations. First, there was a positive and significant indirect effect, a and b, between CG and ESRQ. Second, the direct effect, $c^{\prime}$, between CG and CR was insignificant after including ESRQ, suggesting that ESRQ fully mediates the association between CG and CR.

The results support the third hypothesis, $\mathrm{H} 3$, indicating that ESRQ fully mediates the relationship between CG and CR. This suggests that an effective CG mechanism improves ESRQ and, consequently, improves CR. This finding is also supported by [27], which found that social disclosure fully mediates the impact that having women on boards has on overall corporate reputation. This study suggests that board diversity plays a role in enhancing corporate reputation by contributing to a company's CSR.

The findings of this study are also consistent with agency theory. Effective corporate governance will strengthen companies' internal controls and provide an intensive monitoring package for companies to use in reducing opportunistic behaviour and information asymmetry through ESRQ, thus increasing their overall reputation. Moreover, ESRQ not only has a direct effect on $C R$ but also has fully mediating effects. Therefore, if companies want to improve their corporate reputation, managers must improve their environmental and social reporting quality. 
In conclusion, the main results of the regression analyses support all three hypotheses. Additional analyses are discussed in Section 4.6 to provide a better explanation of the findings.

\subsubsection{The Results of Control Variables and Corporate Reputation}

The results of the control variables are presented in Table 11. The results show that company size (SIZE) was positively and significantly associated with corporate reputation. Large companies tend to have a better corporate image and reputation [26,116]. Return on assets (ROA) was also positively and significantly associated with corporate reputation. This finding is consistent with prior studies $[2,26]$. Moreover, consistent with a prior study [109], Table 11 shows that company growth (MTB) was positively associated with corporate reputation, as shown in models 1,3 and 4 .

The results also indicate that company risk (beta) was positively and significantly associated with corporate reputation, as shown in model 1, which as agrees with the previous findings by Musteen et al., (2010) [25]. However, this finding is inconsistent with the assertion in prior studies $[28,109,117,118]$ that high risk in business negatively impacts corporate reputation. Company leverage (LEV) is not significantly associated with corporate reputation. It has been suggested that a higher level of company debt has a negative impact on reputation [26].

\subsection{Additional Tests}

This section discusses several additional analyses used to provide more explanation and discussion of the main findings. First, an additional test was conducted to investigate the effect of each corporate governance dimensions (board of directors and audit committee) on corporate reputation and ESRQ. Second, an additional test was conducted to examine the impact of corporate governance on the individual corporate reputation dimensions, and a third test was conducted to analyse the impact of ESRQ on the individual corporate reputation dimensions.

4.6.1. Corporate Governance Dimensions on Corporate Reputation (CR) and Environmental and Social Reporting Quality (ESRQ)

Table 13 shows that only the board of directors dimension significantly influenced both $\mathrm{CR}((\mathrm{B}=0.213, \mathrm{t}=2.590, p<0.05)$ and ESRQ $((\mathrm{B}=0.213, \mathrm{t}=2.590, p<0.05)$. This finding indicates that effective board member characteristics help to improve CR and ESRQ. These outcomes support earlier findings suggesting that board members monitoring of organisations' decision-making processes and their involvement in environmental and social activities can improve the reporting quality and corporate reputation.

Table 13 also shows that the audit committee characteristics had insignificant associations with CR and ESRQ. This could have been due to the role of committees focusing more on corporate financial reporting rather than environmental and social reporting. However, this finding is not consistent with past studies [119-121], which found that audit committee characteristics could be more effective in monitoring the company, which would lead to better quality disclosure.

Table 13. Corporate governance dimensions for corporate reputation.

\begin{tabular}{ccc}
\hline Variables & CR & ESRQ \\
\hline \multirow{2}{*}{ Constant } & $-0.844^{* * *}$ & $0.432^{* * *}$ \\
& $(-6.73)$ & $(4.85)$ \\
BOD & $0.192^{*}$ & $0.167^{* *}$ \\
& $(1.78)$ & $(2.18)$ \\
AUD & 0.046 & 0.047 \\
& $(0.60)$ & $(0.85)$ \\
SIZE & $0.077^{* * *}$ & $0.048^{* * *}$ \\
& $(9.11)$ & $(7.87)$ \\
\hline
\end{tabular}


Table 13. Cont.

\begin{tabular}{ccc}
\hline Variables & CR & ESRQ \\
\hline LEV & 0.001 & 0.001 \\
& $(0.14)$ & $(1.57)$ \\
MTB & $0.032^{* *}$ & $0.017^{*}$ \\
& $(2.59)$ & $(1.90)$ \\
ROA & $0.003^{*}$ & 0.001 \\
& $(1.95)$ & $(0.25)$ \\
RISK & $0.032^{* *}$ & $0.019^{*}$ \\
$\mathrm{R}^{2}$ & $(2.05)$ & $(1.73)$ \\
Adjusted $\mathrm{R}^{2}$ & 0.3858 & 0.2793 \\
F Value & 0.3713 & 0.2623 \\
Prob $>\mathrm{F}$ & 26.74 & 16.50 \\
\end{tabular}

*** $p<0.01,{ }^{* *} p<0.05, * p<0.10 . \mathrm{CR}=$ corporate reputation, ESRQ $=$ environmental and social reporting quality, $\mathrm{BOD}=$ board of directors' characteristic, AUD = audit committee characteristic, SIZE = total assets, LEV = leverage (total debts / total Assets), MTB = market to book value, ROA = return on assets, RISK = beta.

4.6.2. Corporate Governance (CG) and Individual Corporate Reputation (CR) Dimensions

Table 14 provides the results of the relationship between the corporate governance (CG) and individual corporate reputation (CR) dimensions (commitment to stakeholders, financial performance, media exposure, brand value and awards received). The results show that corporate governance was only statistically significant in influencing CR, as measured by stakeholder commitment. This indicates that companies with effective corporate governance will have initiatives and remain committed to stakeholders' needs and expectations.

Table 14. Corporate governance and individual corporate reputation dimensions.

\begin{tabular}{|c|c|c|c|c|c|}
\hline Variables & CMMT & FINPER & MEDIA & BRAND & AWARD \\
\hline Constant & $\begin{array}{c}-2.063 * * * \\
(-3.70)\end{array}$ & $\begin{array}{l}-0.732 \\
(-1.65)\end{array}$ & $\begin{array}{c}0.0147 \\
(0.06)\end{array}$ & $\begin{array}{c}-1.713^{* * *} \\
(-11.16)\end{array}$ & $\begin{array}{c}-1.442^{* * *} \\
(-5.43)\end{array}$ \\
\hline CG & $\begin{array}{c}1.081^{* *} \\
(2.08)\end{array}$ & $\begin{array}{l}0.454 \\
(1.10)\end{array}$ & $\begin{array}{l}0.058 \\
(0.25)\end{array}$ & $\begin{array}{l}0.229 \\
(1.60)\end{array}$ & $\begin{array}{l}-0.159 \\
(-0.64)\end{array}$ \\
\hline SIZE & $\begin{array}{c}0.176^{* * *} \\
(4.64)\end{array}$ & $\begin{array}{c}0.071^{* *} \\
(2.36)\end{array}$ & $\begin{array}{c}0.042^{* *} \\
(2.49)\end{array}$ & $\begin{array}{c}0.123^{* * *} \\
(11.83)\end{array}$ & $\begin{array}{c}0.132^{* * * *} \\
(7.34)\end{array}$ \\
\hline LEV & $\begin{array}{l}-0.001 \\
(-0.18)\end{array}$ & $\begin{array}{l}0.001 \\
(0.08)\end{array}$ & $\begin{array}{c}0.003^{* *} \\
(2.75)\end{array}$ & $\begin{array}{l}-0.001^{* *} \\
(-2.06)\end{array}$ & $\begin{array}{l}-0.001 \\
(-0.75)\end{array}$ \\
\hline MTB & $\begin{array}{l}-0.749 \\
(-1.38)\end{array}$ & $\begin{array}{c}0.137^{* *} \\
(3.19)\end{array}$ & $\begin{array}{c}0.058^{* *} \\
(2.40)\end{array}$ & $\begin{array}{c}0.057^{* * *} \\
(3.80)\end{array}$ & $\begin{array}{c}0.048 * \\
(1.86)\end{array}$ \\
\hline ROA & $\begin{array}{l}0.003 \\
(0.51)\end{array}$ & $\begin{array}{c}0.025^{* * *} \\
(5.17)\end{array}$ & $\begin{array}{l}0.001 \\
(0.54)\end{array}$ & $\begin{array}{c}-0.006^{* * *} \\
(-3.78)\end{array}$ & $\begin{array}{l}-0.005 \\
(-1.62)\end{array}$ \\
\hline RISK & $\begin{array}{l}0.068 \\
(0.97)\end{array}$ & $\begin{array}{l}0.082 \\
(1.48)\end{array}$ & $\begin{array}{l}0.012 \\
(0.41)\end{array}$ & $\begin{array}{l}0.004 \\
(0.23)\end{array}$ & $\begin{array}{c}0.062 * \\
(1.86)\end{array}$ \\
\hline $\mathrm{R}^{2}$ & 0.1204 & 0.2215 & 0.1099 & 0.4041 & 0.2254 \\
\hline Adjusted $\mathrm{R}^{2}$ & 0.1027 & 0.2059 & 0.0921 & 0.3921 & 0.2099 \\
\hline F-statistic & 6.82 & 14.18 & 6.16 & 33.79 & 14.5 \\
\hline Prob $>$ F & 0.000 & 0.000 & 0.000 & 0.000 & 0.000 \\
\hline
\end{tabular}

Table 14 also shows that CG had no significant impact on the other CR dimensions: financial performance, media exposure, brand value and awards. A possible reason for the insignificant results could be the limitations of the sample companies' data. For example, only 9.8 per cent of the sample companies were in the list of the Top 100 Companies of Brand Finance and only 28 per cent of the sample companies received awards from external parties. 
4.6.3. Environmental and Social Reporting Quality (ESRQ) and Individual Corporate Reputation (CR) Dimensions

Table 15 shows the results for the association between ESRQ and the CR dimensions. The results show that ESRQ significantly influenced all dimensions of CR. The positive association between ESRQ and CR indicates that disclosure quality sends signals to capital markets and reduces information asymmetry between managers and stakeholders. This result is supported by signalling theory, which argues that companies engage in environmental and social reporting quality to signal to their stakeholders that they are performing better than other companies. This increases their corporate reputation, suggesting that reporting quality is an important tool used to manage corporate reputation $[28,93]$.

Table 15. Disclosure reporting quality and individual corporate reputation dimensions.

\begin{tabular}{|c|c|c|c|c|c|}
\hline Variables & CMMT & FINPER & MEDIA & BRAND & AWARD \\
\hline Constant & $\begin{array}{c}-0.367^{* * *} \\
(-0.93)\end{array}$ & $\begin{array}{c}-0.644^{* * *} \\
(-1.75)\end{array}$ & $\begin{array}{c}0.152^{* * *} \\
(0.74)\end{array}$ & $\begin{array}{c}-1.512 \text { *** } \\
(-11.80)\end{array}$ & $\begin{array}{c}-1.360^{* * *} \\
(-6.25)\end{array}$ \\
\hline ESRQ & $\begin{array}{c}3.386^{* * *} \\
(11.07)\end{array}$ & $\begin{array}{c}-0.643^{* *} \\
(-2.26)\end{array}$ & $\begin{array}{c}0.336^{* *} \\
(2.12)\end{array}$ & $\begin{array}{c}0.189 * \\
(1.91)\end{array}$ & $\begin{array}{c}0.599 * * * \\
(3.56)\end{array}$ \\
\hline SIZE & $\begin{array}{l}0.017 \\
(0.48)\end{array}$ & $\begin{array}{c}0.106^{* *} \\
(3.24)\end{array}$ & $\begin{array}{c}0.026 \\
(1.40)\end{array}$ & $\begin{array}{c}0.116^{* * *} \\
(10.12)\end{array}$ & $\begin{array}{c}0.102 * * * \\
(5.22)\end{array}$ \\
\hline LEV & $\begin{array}{l}0.002 \\
(0.78)\end{array}$ & $\begin{array}{l}-0.001 \\
(-0.15)\end{array}$ & $\begin{array}{c}0.003^{* *} \\
(2.95)\end{array}$ & $\begin{array}{c}0.001 \text { * } \\
(1.91)\end{array}$ & $\begin{array}{l}0.001 \\
(0.41)\end{array}$ \\
\hline MTB & $\begin{array}{c}-0.131^{* *} \\
(-2.83)\end{array}$ & $\begin{array}{c}0.151^{* *} \\
(3.49)\end{array}$ & $\begin{array}{c}0.052^{* *} \\
(2.16)\end{array}$ & $\begin{array}{c}0.054^{* * *} \\
(3.61)\end{array}$ & $\begin{array}{l}0.037 \\
(1.45)\end{array}$ \\
\hline ROA & $\begin{array}{l}0.004 \\
(0.84)\end{array}$ & $\begin{array}{c}0.026^{* * *} \\
(5.34)\end{array}$ & $\begin{array}{l}0.002 \\
(0.57)\end{array}$ & $\begin{array}{c}0.006^{* * *} \\
(3.64)\end{array}$ & $\begin{array}{c}0.005^{*} \\
(1.73)\end{array}$ \\
\hline RISK & $\begin{array}{l}-0.002 \\
(-0.04)\end{array}$ & $\begin{array}{l}0.089 \\
(1.60)\end{array}$ & $\begin{array}{l}0.006 \\
(0.21)\end{array}$ & $\begin{array}{l}0.001 \\
(0.07)\end{array}$ & $\begin{array}{l}0.053 \\
(1.63)\end{array}$ \\
\hline $\mathrm{R}^{2}$ & 0.3671 & 0.2314 & 0.1229 & 0.4062 & 0.5590 \\
\hline Adjusted $\mathrm{R}^{2}$ & 0.3544 & 0.2160 & 0.1053 & 0.3943 & 0.2410 \\
\hline F-statistic & 28.91 & 15.01 & 6.98 & 34.09 & 17.14 \\
\hline Prob $>$ F & 0.000 & 0.000 & 0.000 & 0.000 & 0.000 \\
\hline
\end{tabular}

\subsubsection{Qualitative Case Studies}

This section explains the findings qualitatively, by examining the practices of a sample company, DRB-Hicom Berhad. The company is one of the largest conglomerates in Malaysia with a market capitalisation of RM2.707 billion, and an estimated 56,000 employees globally. The company's principal activities are in the automotive, services and properties sectors.

DRB-Hicom Berhad scored 11 out of 14 for the corporate governance effectiveness indicators, which was among the highest in the sample companies. The high score could have been due to the characteristics of its board members, half of them being independent, with a good mixed of board qualifications, experiences and gender diversity. The company also held more meetings (eight meetings in 2018), more than what is required by the MCCG, indicating board members who are more committed to discuss corporate issues.

According to agency theory, a company with good governance will be able to minimise agency conflict and achieve a better corporate reputation [26]. As mentioned, corporate reputation was measured based the positive media reporting and the awards won at local and international levels. DRB-Hicom Berhad had positive media coverage in The Edge Malaysia more than 50 times in the period of study. Additionally, the company also won more than five awards, including at the Asia Sustainability Reporting Awards (https: / / www.drb-hicom.com/sustainability / awards-recognition/ (accessed on 15 September 2021)) in 2018.These qualitative data support hypothesis 1, which predicted a positive association between corporate governance effectiveness and corporate reputation. Effective 
corporate governance ensures that the board members perform their monitoring roles with more accountability and transparency, which enhances reputation [24].

Additionally, DRB-Hicom Berhad had high environmental and social reporting quality (ESRQ), with an average score of 37 compared to the average score of 22 for the rest of the sample companies (Table 8, panel B). Signalling theory proposes that companies engage in socially responsible activities and report those activities to build connections with stakeholders and anticipate positive outcomes [7]. In this case, the theory predicts that DRB-Hicom Berhad provided the environmental and social reporting in order to improve corporate reputation. These trends for the ESRQ and corporate reputation data of DRBHicom Berhad support hypothesis 2 regarding a positive association between the quality of environmental and social reporting with corporate reputation.

Moreover, hypothesis 3 proposed that corporate reputation is the outcome of effective corporate governance, which improves the quality of environmental and social reporting. High reporting quality fulfils stakeholders' information needs and interests, meets stakeholders' information demands and leads to the improvement of corporate reputation. In other words, effective corporate governance monitors and controls managers so that the quality of their environmental and social reporting improves, which reduces agency costs and, eventually, contributes to companies' corporate reputations. DRB-Hicom Berhad performed well in all these three categories: corporate governance effectiveness, quality of environmental and social reporting and corporate reputation. Therefore, according to agency and signalling theory, the findings support hypothesis 3 that environmental and social reporting quality mediates the relationship between corporate governance effectiveness and corporate reputation.

\section{Conclusions and Implications}

Corporate reputation is a company's most valuable asset. It is a reflection of the company's past performance that sends signals about its possible future performance. It is a logical outcome, among others, of corporate governance effectiveness and corporate social responsibility initiatives that fulfil stakeholder needs.

This study examined the impacts of corporate governance and environmental and social reporting quality on corporate reputation and tested the mediation role of environmental and social reporting quality in the relationship between corporate governance and corporate reputation. This study employed agency and signalling theory to test all the hypotheses. Agency theory proposes that effective corporate governance mechanisms help companies to alleviate various principal-agent conflicts in order to achieve better outcomes. Effective corporate governance ensures that senior management perform their roles and responsibilities with accountability and transparency in order to enhance the company's reputation. This finding is consistent with signalling theory, in that companies engaged in environmental and social reporting quality to improve their reputation from their stakeholders' perspective.

The results of the study reveal that corporate governance and environmental and social reporting quality influence corporate reputation. The results also show that corporate governance significantly influences environmental and social reporting quality. The mediation analysis showed that environmental and social reporting quality fully mediated the relationship between corporate governance and corporate reputation. This finding indicates that an effective corporate governance mechanism could improve the quality of environmental and social reporting disclosure, which would subsequently enhance corporate reputation. The findings are consistent with agency theory, which proposes that effective corporate governance strengthens the internal control of a company. It also provides better monitoring for companies to reduce opportunistic behaviours and information asymmetry through environmental and social reporting quality, which can thus improve companies' reputations. 


\subsection{Research Implications and Contributions}

This study fills a research gap in the literature by providing evidence of the impact of board diversity on corporate reputation in Malaysia. Most previous studies explored the impact of boards of directors on environmental and social reporting. However, very few studies have examined the impact of board diversity on corporate reputation. The results of this study show that board composition and diversity (board independence, diverse educational background, experiences, ethnicity and gender) and the quality of environmental and social reporting play a significant role in influencing corporate reputation. The differences within board membership and diversity in board members' backgrounds bring different perspectives, expertise and knowledge to boardroom discussions and improve the decision-making process. The findings can help companies to set criteria and qualifications when appointing new board members. This means the newly appointed members must satisfy the diversity criteria set by the nomination committee of the board. This diversity requirement is consistent with the MCCG (2017), which proposed that board members must have the right mix of skills, knowledge, experience and independent elements in order to make the best possible decisions and achieve the company's objectives and strategic goals.

This study is also among the first that attempts to provide empirical evidence for the mediation role of environmental and social reporting quality between corporate governance and corporate reputation in developing countries. The results of the mediation analyses indicate that environmental and social reporting quality fully mediates the relationship between corporate governance and corporate reputation. The finding adds to the literature the finding that effective corporate governance is vital for more transparent and higher quality environmental and social reporting.

This study developed a corporate reputation index by combining five different dimensions from internal and external sources: commitment to stakeholders, financial performance, media exposure, brand value and awards received by companies. Such an index adds value to the existing literature on reputation studies. Previous studies from developed countries such as the US, the UK and Spain have used corporate reputational rankings to measure corporate reputation while testing its association with different antecedents and consequences. The reputational ranking has been criticised because such assessments of corporate reputation were only based on surveys of senior management and analysts, who would not necessarily represent all stakeholder groups. Thus, this study contributes by offering a better measurement of a corporate reputation index based on five dimensions, incorporating stakeholder perceptions of companies and other financial and non-financial dimensions, as suggested by past studies.

\subsection{Research Limitations and Future Research}

Several research limitations should be addressed. First, this study used a quantitative research method and collected secondary data from various sources, such as company annual reports, the Brand Finance website and the advanced Google research function. Some information, such as information on environmental and social reporting quality and the stakeholder dimension for corporate reputation, were collected manually from annual reports using a content analysis technique. In order to enhance the understanding of the research phenomena, future research could explore qualitative research methods, such as using detailed structured/unstructured personal interview techniques with senior managers to understand their motivations for providing social and environmental reporting and the role of effective corporate governance on disclosure. This type of detailed interview would uncover other factors that could influence corporate reputation.

Second, this study excluded all companies from the financial, banking, insurance, trust, closed-end funds and securities sectors, since they are subject to different rules and regulations that might have influenced the results of the study. Therefore, the findings of this study cannot be generalised to companies in these sectors. Future studies can be conducted on these financially related companies. Those new findings would add to 
the existing academic literature that explores the financial and banking perspectives of reputational studies.

Author Contributions: Conceptualization, M.I.G., R.J., N.M.S. and M.H.Y.; methodology, M.I.G., R.J. and M.H.Y.; validation, M.I.G., R.J. and M.H.Y.; investigation, M.I.G., R.J.; resources, M.I.G., R.J.; writing—original draft preparation, M.I.G.; writing—review and editing, M.I.G., R.J., N.M.S. and M.H.Y.; visualization, R.J.; supervision, R.J., N.M.S. and M.H.Y.; project administration, R.J., N.M.S. and M.H.Y.; funding acquisition, M.I.G., R.J. All authors have read and agreed to the published version of the manuscript.

Funding: The APC was funded by Faculty of Economics and Management, Universiti Kebangsaan Malaysia: EP-2018-001.

Institutional Review Board Statement: Not applicable.

Informed Consent Statement: Not applicable.

Conflicts of Interest: The authors declare no conflict of interest.

\section{References}

1. Deephouse, D.L. Media Reputation as a Strategic Resource: An Integration of Mass Communication and Resource-Based Theories. J. Manag. 2000, 26, 1091-1112. [CrossRef]

2. Roberts, P.W.; Dowling, G.R. Corporate reputation and sustained superior financial performance. Strat. Manag. J. 2002, 23, 1077-1093. [CrossRef]

3. Michelon, G. Sustainability Disclosure and Reputation: A Comparative Study. Corp. Reput. Rev. 2011, 14, 79-96. [CrossRef]

4. De Quevedo-Puente, E.; De La Fuente-Sabaté, J.M.; Fombrun, C.J. Corporate Social Performance and Corporate Reputation: Two Interwoven Perspectives. Corp. Reput. Rev. 2007, 10, 60-72. [CrossRef]

5. Deloitte. Global Survey on Reputation Risk, 2014. Available online: www.deloitte.com/reputationrisksurvey (accessed on 15 June 2019).

6. Brammer, S.; Pavelin, S. Building a Good Reputation. Eur. Manag. J. 2004, 22, 704-713. [CrossRef]

7. Pérez, A. Corporate reputation and CSR reporting to stakeholders. Corp. Commun. Int. J. 2015, 20, 11-29. [CrossRef]

8. Davies, R.; Chun, R.; Roper, S. Corporate reputation and competitiveness. Corp. Reput. Rev. 2003, 5, 368-370.

9. Smaiziene, I.; Jucevicius, R. Corporate Reputation: Multidisciplinary Richness and Search for a Relevant Definition. Focus 2009, $62,91-102$.

10. Shamma, H.; Hassan, S. Customer and non-customer perspectives for examining corporate reputation. J. Prod. Brand Manag. 2009, 18, 326-337. [CrossRef]

11. Fombrun, C.J.; Van Riel, C. The Reputational Landscape. Corp. Reput. Rev. 1997, 1, 5-13. [CrossRef]

12. Fombrun, C.J. Reputation: Realizing Value from the Corporate Image; Harvard Business School Press: Boston, MA, USA, 1996.

13. Waddock, S. The multiple bottom lines of corporate citizenship: Social investing, reputation, and responsibility audits. Bus. Soc. Rev. 2000, 105, 323-345. [CrossRef]

14. Hillenbrand, C.; Money, K. Corporate responsibility and corporate reputation: Two separate concepts or two sides of the same coin? Corp. Reput. Rev. 2007, 10, 261-277. [CrossRef]

15. Lourenço, I.C.; Callen, J.L.; Branco, M.C.; Curto, J.D. The Value Relevance of Reputation for Sustainability Leadership. J. Bus. Ethics 2014, 119, 17-28. [CrossRef]

16. Liston-Heyes, C.; Ceton, G. An investigation of real versus perceived CSP in S \& P-500 firms. J. Bus. Ethics 2009, 89, $283-296$.

17. Dyer, J.H.; Chu, W. The role of trustworthiness in reducing transaction costs and improving performance: Empirical evidence from the United States, Japan, and Korea. Organ. Sci. 2003, 14, 57-68. [CrossRef]

18. Dowling, G.R. Corporate reputations: Should you compete on yours? Calif. Manag. Rev. 2004, 46, 19-36. [CrossRef]

19. Barney, J. Firm resources and sustained competitive advantage. J. Manag. 1991, 17, 99-120. [CrossRef]

20. Surroca, J.; Tribó, J.A.; Waddock, S. Corporate responsibility and financial performance: The role of intangible resources. Strateg. Manag. J. 2010, 31, 463-490. [CrossRef]

21. Carlisle, Y.; Faulkner, D. The strategy of reputation. Strateg. Chang. 2005, 14, 413-422. [CrossRef]

22. Sanchez, J.L.F.; Sottorio, L.L.; Diez, E.B. The relationship between corporate social responsibility and corporate reputation in a turbulent environment: Spanish evidence of the Ibex35 firms. Corp. Gov. Int. J. Bus. Soc. 2015, 15, 563-575.

23. Dowling, G. Reputation risk: It is the board's ultimate responsibility. J. Bus. Strategy 2006, 27, 59-68. [CrossRef]

24. Radbourne, J. Performing on boards: The link between governance and corporate reputation in nonprofit arts boards. Corp. Reput. Rev. 2003, 6, 212-222. [CrossRef]

25. Musteen, M.; Datta, D.K.; Kemmerer, B. Corporate reputation: Do board characteristics matter? Br. J. Manag. 2010, 21, 498-510. [CrossRef]

26. Bravo, F.; Abad, C.; Briones, J. The board of directors and corporate reputation: An empirical analysis. Acad. Rev. Latinoam. Adm. 2015, 28, 359-379. [CrossRef] 
27. Bear, S.; Rahman, N.; Post, C. The impact of board diversity and gender composition on corporate social responsibility and firm reputation. J. Bus. Ethics 2010, 97, 207-221. [CrossRef]

28. Toms, J.S. Firm resources, quality signals and the determinants of corporate environmental reputation: Some UK evidence. $\mathrm{Br}$. Account. Rev. 2002, 34, 257-282. [CrossRef]

29. De los Ríos, A.; Ruiz, M.; Tirado, P. An approach to the relationship between the information about Spanish financial entities' social responsibility with respect to customers and their own corporate reputation. Cuad. Econ. Dir. Empresa 2012, 15, 130-140.

30. Fombrun, C.J. The Leadership Challenge: Building Resilient Corporate Reputations, Handbook on Responsible Leadership and Governance in Global Business; Edward Elgar: Chektenham, UK, 2005; pp. 54-68.

31. Ferns, B.; Emelianova, O.; Sethi, S.P. In His Own Words: The Effectiveness of CEO as Spokesperson on CSR-Sustainability Issues-Analysis of Data from the Sethi CSR Monitor. Corp. Reput. Rev. 2008, 11, 116-129. [CrossRef]

32. Bertels, S.; Peloza, J. Running to Stand Still: Managing CSR Reputation in an Era of Ratcheting Expectations. Corp. Reput. Rev. 2008, 11, 56-72. [CrossRef]

33. Hanzaee, K.H.; Sadeghian, M. The impact of corporate social responsibility on customer satisfaction and corporate reputation in automotive industry: Evidence from Iran. J. Islamic Mark. 2014, 5, 125-143. [CrossRef]

34. Fatma, M.; Rahman, Z.; Khan, I. Building company reputation and brand equity through CSR: The mediating role of trust. Int. J. Bank Mark. 2015, 33, 840-856. [CrossRef]

35. Grewal, D.; Darlow, N.J. The business paradigm for corporate social reporting in the context of Australian seaports. Marit. Econ. Logist. 2007, 9, 172-192. [CrossRef]

36. Vitolla, F.; Raimo, N.; Rubino, M. Board characteristics and integrated reporting quality: An agency theory approach. Corp. Soc. Responsib. Environ. Manag. 2020, 27, 1152-1163. [CrossRef]

37. Fombrun, C.J. RI insights: Corporate governance. Corp. Reput. Rev. 2006, 8, 267-271. [CrossRef]

38. Garcia-Sanchez, I.M.; Raimo, N.; Vitolla, F. CEO power and integrated reporting. Meditari Account. Res. 2021, $29,908-942$. [CrossRef]

39. Cadbury, R. Report of the Committee on the Financial Aspects of Corporate Governance; Gee and Co. Publishing Ltd. (Professional Publishing Ltd.): London, UK, 1992.

40. Mirsha, S.; Mohanty, P. Corporate governance as a value driver for firm performance: Evidence from India. Corp. Gov. 2014, 14, 265-280.

41. Goyal, R.; Kakabadse, N.; Kakabadse, A. Improving corporate governance with functional diversity on FTSE 350 boards: Directors' perspective. J. Cap. Mark. Stud. 2019, 3, 116-136. [CrossRef]

42. Said, R.; Zainuddin, Y.H.; Haron, H. The relationship between corporate social responsibility disclosure and corporate governance characteristics in Malaysian public listed companies. Soc. Responsib. J. 2009, 5, 212-226. [CrossRef]

43. Hartmann, C.; Carmenate, J. Does board diversity influence firms' corporate social responsibility reputation? Soc. Responsib. J. 2020. [CrossRef]

44. Jouber, $\mathrm{H}$. Is the effect of board diversity on CSR diverse? New insights from one-tier vs two-tier corporate board models. Corp. Gov. 2021, 21, 23-61. [CrossRef]

45. Baker, H.K.; Anderson, R. (Eds.) Corporate Governance: A Synthesis of Theory, Research, and Practice; John Wiley \& Sons Inc.: Hoboken, NJ, USA, 2010; pp. 225-242.

46. Miliken, F.J.; Martins, L.L. Searching for common threads: Understanding the multiple effects of diversity in organizational groups. Acad. Manag. Rev. 1996, 21, 402-433. [CrossRef]

47. Rao, K.; Tilt, C. Board diversity and CSR reporting: An Australian study. Meditari Account. Res. 2016, 24, 182-210. [CrossRef]

48. Patelli, L.; Prencipe, A. The relationship between voluntary disclosure and independent directors in the presence of a dominant shareholder. Eur. Account. Rev. 2007, 16, 5-33. [CrossRef]

49. Haniffa, R.M.; Cooke, T.E. The impact of culture and governance on corporate social reporting. J. Account. Public Policy 2005, 24, 391-430. [CrossRef]

50. Gul, F.A.; Srinidhi, B.; Ng, A.C. Does board gender diversity improve the informativeness of stock prices? J. Account. Econ. 2011, 51, 314-338. [CrossRef]

51. Zhang, L. Board demographic diversity, independence, and corporate social performance. Corp. Gov. Int. J. Bus. Soc. 2002, 12, 686-700. [CrossRef]

52. Makkonen, T.; Williams, A.M.; Habersetzer, A. Foreign board members and firm innovativeness: An exploratory analysis for setting a research agenda. Corp. Gov. Int. J. Bus. Soc. 2018, 18, 1057-1073. [CrossRef]

53. Arora, A.; Sharma, C. Corporate governance and firm performance in developing countries: Evidence from India. Corp. Gov. Int. J. Bus. Soc. 2006, 16, 420-436. [CrossRef]

54. Francoeur, C.; Labelle, R.; Sinclair-Desgagne, B. Gender diversity in corporate governance and top management. J. Bus. Ethics 2008, 81, 83-95. [CrossRef]

55. Brammer, S.; Millington, M.; Pavelin, S. Corporate reputation and women on the board. Br. J. Manag. 2009, 20, 17-29. [CrossRef]

56. Agrawal, A.; Knoeber, C.R. Firm Performance and Mechanisms to Control Agency Problems Be- tween Managers and Shareholders. J. Financ. Quant. Anal. 1996, 31, 377-397. [CrossRef]

57. Lu, Y.; Abeysekera, I.; Cortese, C. Corporate social responsibility reporting quality, board characteristics and corporate social reputation: Evidence from China. Pac. Account. Rev. 2015, 27, 95-118. [CrossRef] 
58. Adams, C.A. A commentary on: Corporate social responsibility reporting and reputation risk management. Account. Audit. Account. J. 2008, 21, 365-370. [CrossRef]

59. Bebbington, J.; Higgins, C.; Frame, B. Initiating sustainable development reporting: Evidence from New Zealand. Account. Audit. Account. J. 2008, 22, 588-625. [CrossRef]

60. Colleoni, E. CSR communication strategies for organizational legitimacy in social media. Corp. Commun. Int. J. 2013, 18, 228-248. [CrossRef]

61. Unerman, J. Strategic reputation risk management and corporate social responsibility reporting. Account. Audit. Account. J. 2008, 21, 362-364. [CrossRef]

62. UNEP. The Global Reporters: First International Survey of Corporate Sustainability Reporting; UNEP: London, UK, 2002.

63. KPMG. International Survey of Corporate Responsibility Reporting; KPMG: London, UK, 2005.

64. Jain, R.; Winner, L.H. CSR and sustainability reporting practices of top companies in Indianull. Corp. Commun. Int. J. 2016, 21, 36-55. [CrossRef]

65. Melo, T.; Garrido-Morgado, A. Corporate Reputation: A Combination of Social Responsibility and Industry. Corp. Soc. Responsib. Environ. Manag. 2012, 19, 11-31. [CrossRef]

66. Hur, W.M.; Kim, H.; Woo, J. How CSR Leads to Corporate Brand Equity: Mediating Mechanisms of Corporate Brand Credibility and Reputation. J. Bus. Ethics 2014, 125, 75-86. [CrossRef]

67. Maden, C.; Arıkan, E.; Telci, E.E.; Kantur, D. Linking Corporate Social Responsibility to Corporate Reputation: A Study on Understanding Behavioral Consequences. Proc.-Soc. Behav. Sci. 2012, 58, 655-664. [CrossRef]

68. McWilliams, A.; Siegel, D.S.; Wright, P.M. Guest Editors' Introduction Corporate Social Responsibility: Strategic Implications. J. Manag. Stud. 2006, 43, 1-18. [CrossRef]

69. Hsu, K.-T. The Advertising Effects of Corporate Social Responsibility on Corporate Reputation and Brand Equity: Evidence from the Life Insurance Industry in Taiwan. J. Bus. Ethics 2012, 109, 189-201. [CrossRef]

70. Freundlieb, M.; Gräuler, M.; Teuteberg, F. A conceptual framework for the quality evaluation of sustainability reports. Manag. Res. Rev. 2014, 37, 19-44. [CrossRef]

71. Abdullah, Z.; Abdul Aziz, Y. Institutionalizing corporate social responsibility: Effects on corporate reputation, culture, and legitimacy in Malaysia. Soc. Responsib. J. 2013, 9, 344-361. [CrossRef]

72. Spence, M. Job market signaling. Q. J. Econ. 1973, 87, 355-374. [CrossRef]

73. Mukasa, K.D.; Kim, K.; Lim, H. How Do Corporate Social Responsibility Influence Corporate Reputation? Evidence from Korean Firms. J. Appl. Bus. Res. 2015, 31, 383-396. [CrossRef]

74. Wang, Z.; Sarkis, J. Corporate Social Responsibility Governance, Outcomes, and Financial Performance. J. Clean. Prod. 2017, 162, 1607-1616. [CrossRef]

75. Zhou, L. Social responsibility and employees' organizational identification in Chinese family firms: Influence of family ownership and family commitment. Chin. Manag. Stud. 2014, 8, 683-703. [CrossRef]

76. Sial, M.S.; Zheng, C.; Cherian, J.; Gulzar, M.A.; Thu, P.A.; Khan, T.; Khuong, N.V. Does Corporate Social Responsibility Mediate the Relation between Boardroom Gender Diversity and Firm Performance of Chinese Listed Companies? Sustainability 2018, 10, 3591. [CrossRef]

77. Fama, E.; Jensen, M. Separation of ownership and control. J. Law Econ. 1983, 26, 301-326. [CrossRef]

78. Hillman, A.J.; Dalziel, T. Boards of directors and firm performance: Integrating agency and resource dependence perspective. Acad. Manag. Rev. 2003, 28, 383-396. [CrossRef]

79. Hashim, F.; Saleh, N. Voluntary Annual Report Disclosures by Malaysian Multinational Corporations. Malays. Account. Rev. 2007, $6,129-156$

80. Sekaran, U.; Bougie, R. Research Methods for Business: A Skill-Building Approach, 6th ed.; John Wiley \& Sons Inc.: New York, NY, USA, 2013.

81. Krejcie, R.; Morgan, D. Determining Sample Size for Research Activities Robert. Educ. Psychol. Meas. 1970, 38, 607-610. [CrossRef]

82. Harjoto, M.A.; Salas, J. Strategic and institutional sustainability: Corporate social responsibility, brand value, and Interbrand listing. J. Prod. Brand Manag. 2017, 26, 545-558. [CrossRef]

83. Anas, A.; Majdi, H.; Rashid, A.; Annuar, H.A. The effect of award on CSR disclosures in annual reports of Malaysian PLCs. Soc. Responsib. J. 2015, 11, 831-852. [CrossRef]

84. Deng, B.; Lie, J.W.; Ji, L. Awards and executives' financial performance preference Evidence from China A-share listed companies. Nankai Bus. Rev. Int. 2020, 11, 409-439. [CrossRef]

85. Aguinis, H.; Suarez-Gonzalez, I.; Lannelongue, G.; Joo, H. Scholarly impact revisited. Acad. Manag. Perspect. 2012, 26, 105-132. [CrossRef]

86. Garcia-Sanchez, I.M.; Cuadrado-Ballesteros, B.; Sepulveda, C. Does media pressure moderate CSR disclosures by external directors? Manag. Decis. 2014, 52, 1014-1045. [CrossRef]

87. Aldhamari, R.; Nor, M.N.M.; Boudiab, M.; Mas'ud, A. The impact of political connection and risk committee on corporate financial performance: Evidence from financial firms in Malaysia. Corp. Gov. 2020, 20, 1281-1305. [CrossRef]

88. Lisic, L.L. Auditor-provided tax services and earnings management in tax expense: The importance of audit committees. J. Account. Audit. Financ. 2014, 29, 340-366. [CrossRef] 
89. Al-Dhamari, R.; Almagdoub, A.; Al-Gamrh, B. Are audit committee characteristics important to the internal audit budget in Malaysian firms. Contaduria Adm. 2018, 63, 947-969.

90. Saleh, M.; Zulkifli, N.; Muhamad, R. Corporate social responsibility disclosure and its relation on institutional ownership. Manag. Audit. J. 2011, 25, 591-613. [CrossRef]

91. Ahmed Haji, A. Corporate social responsibility disclosures over time: Evidence from Malaysia. Manag. Audit. J. 2013, 28, 647-676. [CrossRef]

92. Gujarati, D.N. Basic Econometrics, 4th ed.; McGraw-Hill Higher Education: New York, NY, USA, 2003.

93. Hasseldine, J.; Salama, A.I.; Toms, J.S. Quantity versus quality: The impact of environmental disclosures on the reputations of UK Plcs. Br. Account. Rev. 2005, 37, 231-248. [CrossRef]

94. La Porta, R.; Lopez-de-Silanes, F.; Shleifer, A.; Vishny, R.W. Agency problems and dividend policies around the world. J. Financ. 2000, 55, 1-33. [CrossRef]

95. Amran, A.; Rosli, B.A.M.; Mohd-Hassan, B.C.H. Risk reporting: An exploratory study on risk management disclosure in Malaysian annual reports. Manag. Audit. J. 2009, 21, 39-57. [CrossRef]

96. Anwar, N.A.B.M. Association between Disclosure Quality and Stock Return with the Moderating Effects of Corporate Governance Practices and Ownership Structure in Malaysia. Ph.D. Thesis, University Putra Malaysia, Serdang, Malaysia, 2016.

97. Claessens, S.; Djankov, S.; Lang, L. The separation of ownership and control in East Asian Corporations. J. Financ. Econ. 2000, 58, 81-112. [CrossRef]

98. Adinehzadeh, R. Corporate Governance and Quality of Environmental Disclosure: The Role of Environmental Performance. Ph.D. Thesis, University Kebangsaan Malaysia, Bangi, Malaysia, 2016.

99. Iatridis, G.E. Environmental disclosure quality: Evidence on environmental performance, corporate governance and value relevance. Emerg. Mark. Rev. 2013, 14, 55-75. [CrossRef]

100. Habbash, M. Corporate governance and corporate social responsibility disclosure: Evidence from Saudi Arabia. Soc. Responsib. J. 2016, 12, 740-754. [CrossRef]

101. Harjoto, M.; Laksamana, I.; Lee, R. Board diversity and corporate social responsibility. J. Bus. Ethics 2015, 132, 641-660. [CrossRef]

102. Perez, A.; Salmones, M.D.M.G.; Lopez, C. Corporate reputation in the Spanish Context: An interaction between reporting to stakeholders and industry. J. Bus. Ethics 2015, 129, 733-746. [CrossRef]

103. Brown, P.; Beekes, W.; Verhoeven, P. Corporate governance, accounting and finance: A review. Account. Financ. 2011, 51, 96-172. [CrossRef]

104. Baron, R.M.; Kenny, D.A. The moderator- mediator variable distinction in social psychological research: Conceptual, strategic, and statistical considerations. J. Personal. Soc. Psychol. 1986, 51, 1173-1182. [CrossRef]

105. Hussain, M.; Hadi, A. Corporate governance, risky business and construction industry: A divergence between Bursa and Construction Industry Development Board (CIDB) Klang Valley, Malaysia. Corp. Gov. 2019, 19, 438-457. [CrossRef]

106. Katmon, N.; Mohamad, Z.Z.; Norwani, N.M.; Al Farooque, O. Comprehensive board diversity and quality of corporate social responsibility disclosure: Evidence from Emerging market. J. Bus. Ethics 2017, 157, 447-481. [CrossRef]

107. Ibrahim, A.H.; Hanefah, M.M. Board diversity and corporate social responsibility in Jordan. J. Financ. Report. Account. 2016, 14, 279-298. [CrossRef]

108. Mohamad Nor, M.N.; Shafie, R.; Wan Hussin, W.N. Corporate governance and audit lag. Asian Acad. Manag. J. Account. Financ. 2010, 6, 54-57.

109. Fombrun, C.J.; Shanley, M. What's in a name? Reputation building and corporate strategy. Acad. Manag. J. 1990, 33, $233-258$.

110. Mohammadi, S.; Saeidi, H.; Naghshbandi, N. The impact of board and audit committee characteristics on corporate social responsibility: Evidence from the Iranian stock exchange. Int. J. Product. Perform. Manag. 2020. [CrossRef]

111. Esen, E. The influence of corporate social responsibility (CSR) on building corporate reputation. Int. Bus. Sustain. Corp. Soc. Responsib. 2013, 11, 133-150.

112. Lee, E.; Walker, M.; Zeng, C. Do Chinese state subsidies affect voluntary corporate social responsibility disclosure? J. Account. Public Policy 2017, 36, 179-200. [CrossRef]

113. Jeffrey, S.; Rosenberg, S.; McCage, B. Corporate social responsibility behaviors and corporate reputation. Soc. Responsib. J. 2019, 15, 395-408. [CrossRef]

114. Khojastehpour, M.; Johns, R. The effect of environmental CSR issues on corporate/brand reputation and corporate profitability. Eur. Bus. Rev. 2014, 26, 30-37. [CrossRef]

115. Bayoud, N.; Kavanagh, M. Corporate social responsibility disclosure: Evidence from Libyan managers. Glob. J. Bus. Res. 2012, 6, 73-84.

116. Odriozola, M.D.; Martin, A.; Luna, L. The relationship between labour social responsibility practices and reputation. Int. J. Manpow. 2015, 36, 236-251. [CrossRef]

117. Kaur, A.; Singh, B. Disentangling the reputation-Performance paradox: Indian evidence. J. Indian Bus. Res. 2020, $12,153-167$. [CrossRef]

118. Brammer, S.; Pavelin, S. Voluntary environmental disclosures by large UK companies. J. Bus. Financ. Account. 2006, 33, 1168-1188. [CrossRef]

119. Appuhami, R.; Tashakor, S. The Impact of Audit Committee Characteristics on CSR Disclosure: An Analysis of Australian Firms. Aust. Account. Rev. 2017, 27, 400-420. [CrossRef] 
120. Khan, A.; Muttakin, M.; Siddiqui, J. Corporate governance and corporate social responsibility disclosure: Evidence from an emerging economy. J. Bus. Ethics 2013, 114, 207-223. [CrossRef]

121. Othman, R.; Ishak, I.F.; Arif, S.M.M.; Aris, N.A. Influence of audit committee characteristics on voluntary ethics disclosure. Soc. Behav. Sci. 2014, 145, 330-342. [CrossRef] 